\title{
用于聚合物太阳电池的低成本高效聚合物给体光伏材料
}

刘忠范

北京大学化学与分子工程学院, 北京 100871

\section{Low Cost and High Efficiency Polymer Donor Photovoltaic Materials for Polymer Solar Cells}

\section{LIU Zhongfan}

College of Chemistry and Molecular Engineering, Peking University, Beijing 100871, P. R. China.

Email: zfliu@pku.edu.cn
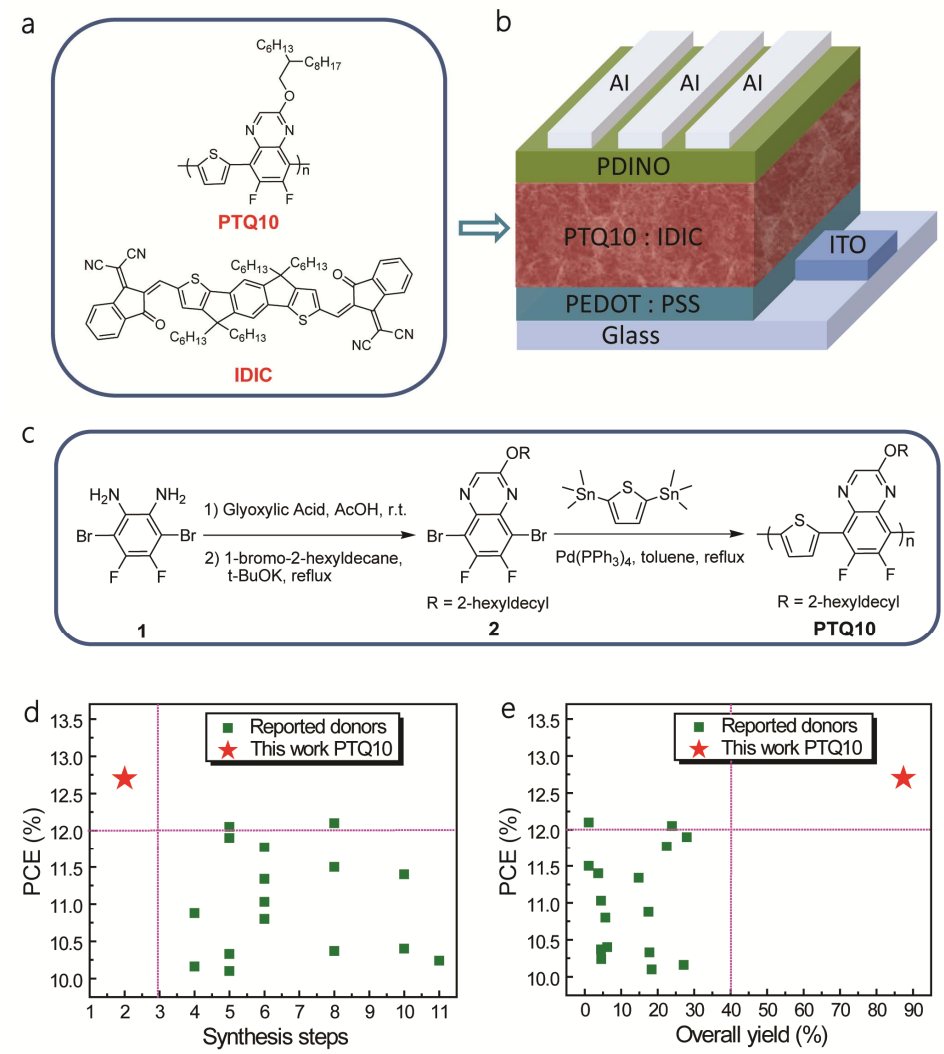

(a)给体 PTQ10 和受体 IDIC 的分子结构; (b) 电池器件结构图; (c) PTQ10 的合成路线;

$(d, e)$ 聚合物太阳电池给体材料合成步骤、产率与效率的对比分析图

聚合物太阳电池由 $p$-型共轭聚合物给体和富 勒烯衍生物或非富勒烯 $n$-型有机半导体受体的共 混活性层夹在透明导电电极和金属电极之间所组 成, 具有可溶液加工、质量轻、以及可制备成柔性
和半透明器件等突出优点, 近年来成为能源领域 研究的热点 ${ }^{1}$ 。聚合物太阳电池的商业应用需要实 现器件的高效率、高稳定性以及低成本, 这主要依 赖于光伏材料的发展。 
聚合物太阳电池研究的早期阶段, 器件效率 很低, 研究的关注点主要是提高效率, 通过设计和 合成窄带系、宽吸收和具有较低最高占有分子轨 道(HOMO) 能级的聚合物给体光伏材料, 以及具有 较高最低空分子轨道(LUMO) 能级的富勒烯衍生 物受体光伏材料, 来提高器件的短路电流、开路电 压和能量转换效率。近年来, 随着窄带隙非富勒烯 $n$-型有机半导体受体光伏材料以及与之吸收互补 的宽带隙聚合物给体光伏材料的发展, 聚合物太 阳电池的能量转换效率获得快速提升, 最近实验 室小面积器件的效率已经突破 $12 \%-13 \%$, 达到了 可以向实际应用发展的门槛。因此, 提高稳定性和 降低成本就成为了实现聚合物太阳电池实际应用 的关键。但是, 当前已报道的高效光伏材料大多结 构复杂、合成困难, 很难满足商业应用的需求。开 发低成本高效光伏材料是聚合物太阳电池实现商 业应用的巨大挑战。

最近, 中国科学院化学研究所李永舫研究组 设计并合成了一个低成本高效的聚合物给体材料 PTQ10 (分子结构见图a), 相关研究成果发表在近 期的 Nature Communications 上 ${ }^{2}$ 。PTQ10 是一种 结构简单的给体-受体(D-A)共聚物, 其中噻吩环作 为给体单元、喹喔啉作为受体单元。在喹喔啉上引 入烷氧基侧链是为了提高聚合物的溶解性并增强
光吸收、引入双氟原子取代以降低聚合物的 HOMO 能级和提高空穴迁移率。该分子可以通过 廉价的原材料两步合成(图 c), 并且总产率接近 $90 \%$, 使得该材料的成本大大降低。更重要的是, 使用 PTQ10 为给体、结构相对简单的 $n$-型有机半 导体 IDIC (图 a) 为受体制备的聚合物太阳电池(器 件结构见图 b)的最高能量转换效率达到 $12.70 \%$, 同时反向结构器件的效率也达到了 $12.13 \%$ (由中 国计量科学研究院确认的效率为 $12 \%)$ 。而且活性 层厚度在 100-300 nm 范围内器件效率都能超过 $10 \%$, 这非常有利于器件的大面积制备。与当前文 献报道的效率超过 $10 \%$ 的其它高效聚合物给体光 伏材料相比, PTQ10 无论是合成步骤、产率和效 率上都具有非常突出的优势 (见图 $d, e$ )。考虑到低 成本、高效率和厚度不敏感等优点, PTQ10 极有 希望成为聚合物太阳电池商业应用中的聚合物给 体材料。

\section{References}

(1) Li, Y. F. Acc. Chem. Res. 2012, 45, 723. doi: 10.1021/ar2002446

(2) Sun, C.; Pan, F.; Bin, H.; Zhang, J.; Xue, L.; Qiu, B.; Wei, Z.; Zhang, Z.; Li, Y. F. Nat. Commun. 2018, 9, 743.

doi: 10.1038/s41467-018-03207-x 